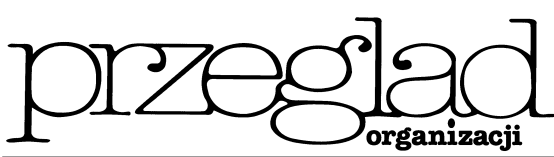

\title{
Badanie efektów wdrożenia zintegrowanego systemu zarządzania jakością zgodnego
z ISO 9001 i ISO 14001
}

https://doi.org/10.33141/po.2005.02.08

Przegląd Organizacji, Nr 2 (781), 2005, ss. 36-38 www.przegladorganizacji.pl Towarzystwo Naukowe Organizacji i Kierownictwa (TNOiK)

Jacek Mazurkiewicz, Marzena Mendzik, Janusz Kliś

\section{Wprowadzenie}

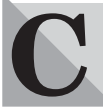

elem opracowania jest prezentacja i ocena zmian powstałych w wyniku wprowadzenia wspólnego dla 4 oddziałów zakładu zintegrowanego systemu zarządzania jakością oraz elektronicznego przesyłu dokumentów[1]. Jeżeli w opracowaniu jest mowa o ZSZJ, to autorzy mają na myśli zintegrowanie dla 4 oddziałów zakładu SZJ zgodnych z normą z PN-EN ISO 9001:1994 w jeden system oparty na normie PN-EN ISO 9001:2000 oraz PN-EN ISO 14001.

W opracowaniu przedstawione są założenia stawiane przed wprowadzonymi w zakładzie zmianami i ich realizacją.

Wprowadzone zmiany to:

- zintegrowanie SZJ 4 oddziałów w jeden system oparty na ISO 9001:2000,

- wprowadzenie elektronicznej wersji dokumentacji systemowej częściowo dzięki wdrożeniu zintegrowanego systemu zarządzania przedsiębiorstwem SAP R/3.
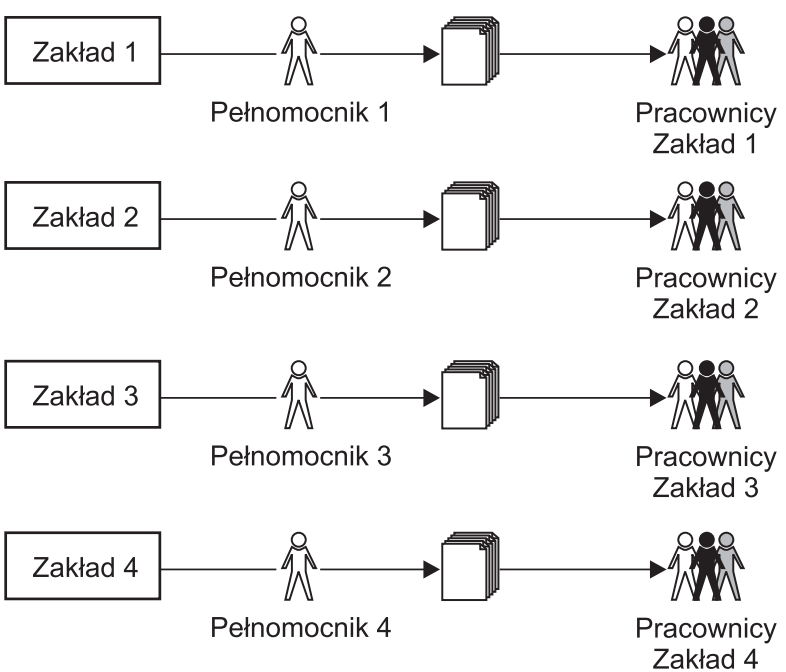

Rys. 1. Sytuacja przedsiębiorstwa przed wprowadzonymi zmianami
Do badań wykorzystano ankiety [2], których uzupełnieniem była analiza dokumentacji źródłowej, wywiady z pracownikami, ocena korzyści zmian, audyty wewnętrzne.

\section{Metodyka i wyniki badań}

\section{Szacunki}

Sytuacja w zakładzie przed wprowadzeniem zmian: każdy z zakładów posiadał SZJ, nadzorowany przez pełnomocnika (rys. 1), a dokumenty systemowe funkcjonowały w wersji drukowanej.

Scalenie (restrukturyzacja) oddziałów w jeden zakład macierzysty oraz zintegrowanie SZJ nadzorowanego teraz przez jednego pełnomocnika powinno pozwolić na obniżenie kosztu certyfikacji oraz kosztu utrzymania stanowiska pełnomocnika [3]. Dodatkowo wprowadzenie elektronicznego przesyłu dokumentacji miało pozwolić na zmniejszenie biurokracji i obciażenia pracowników, a tym samym na obniżenie kosztu utrzymania dokumentacji systemowej (w tym także zużycia papieru) - zob. rys. 2 .

\section{Ankieta}

Badania ankietowe zostały przeprowadzone we wrześniu 2003 roku na próbie 12 pracowników zakładu. Wśród nich byli: kierownik produkcji, kontroler, czterech pracowników biurowych, audytor wewnętrzny SJ, pięciu brygadzistów. Każdy z respondentów odpowiadał na 15 pytań pośrednich, faktyczny cel zadanego pytania nie był znany respondentom [5]. Wybór techniki pytań pośrednich wynikał z niemożności zapewnienia prawdziwych odpowiedzi na temat stosowanego u nich systemu zarządzania jakością prowadzonego przez nich samych. Złe wyniki działania systemu obciążałyby respondentów, a tym samym poddawały w wątpliwość potrzebę tego systemu i sens wykonanej pracy. Przyjęto zatem zasadę zadawania pytań nie dotyczących bezpośrednio pracy respondentów, SZJ czy warunków pracy. Zastosowano natomiast w kilku przypadkach sprawdzanie projekcji ich doświadczeń na sytuacje analogiczne do tych, które ich 


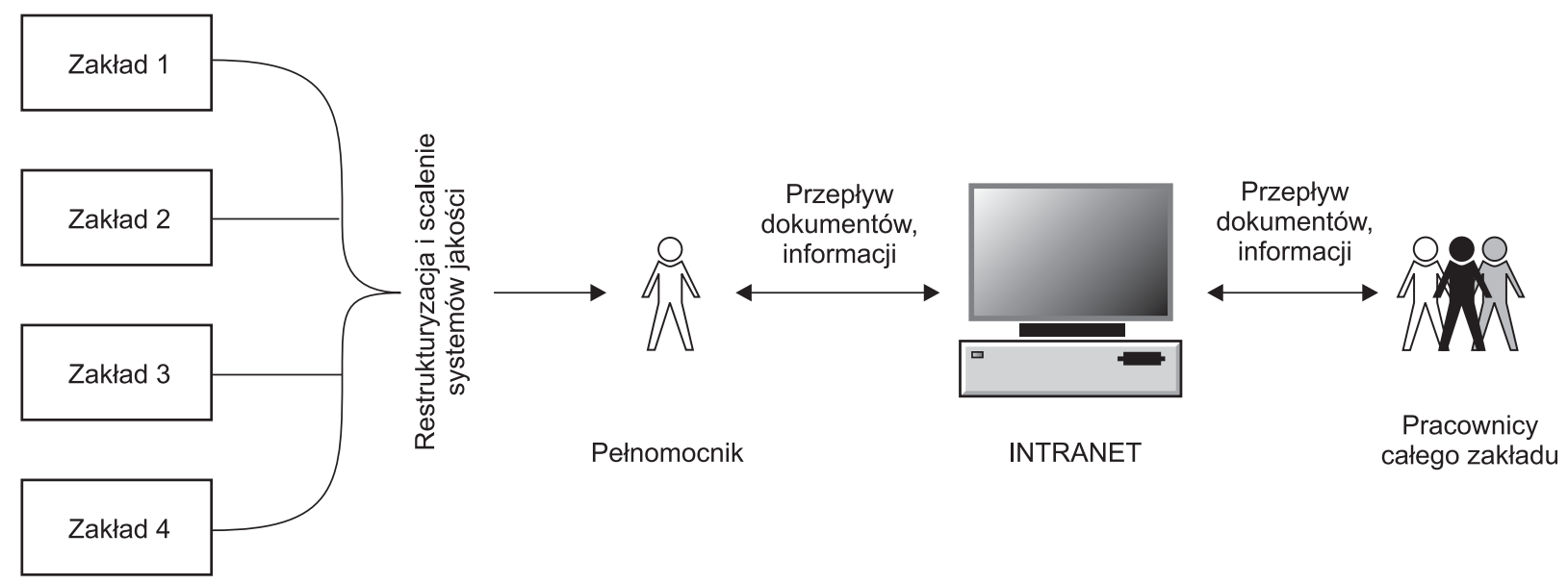

\section{Rys. 2. Sytuacja przedsiębiorstwa po wprowadzonych zmianach}

dotyczą. Odpowiedzi na pytania podzielono na dwie grupy w celu opracowania w rozkładzie dwumianowym oraz czytelnej prezentacji algorytmu oceny. Sama ocenę szczególnie dla większej liczby ankietowanych najlepiej wykonywać stosując arkusz kalkulacyjny, co zazwyczaj czyniono także w tym przypadku.

Analiza została przeprowadzona pod względem wcześniej ustalonych pytań głównych, które pomogły odpowiedzieć na postawiony cel ankiety:

A. Czy pracownicy posiadaja dostateczna wiedze z zakresu systemu zarządzania jakościa?

B. Czy pracownicy przechodzili szkolenia $i$ czy byty one efektywne?

C. Jaki jest stosunek pracowników do nowo wdrożonego ZSZJ w aspekcie ich uczestnictwa?

D. Czy wdrożenie ZSZJ wptynęto na zwiększenie obcią̇enia pracowników?

Aby uzyskać odpowiedź na powyższe pytania główne, konieczne było przeprowadzenie analizy odpowiedzi na co najmniej trzy pytania pośrednie zadawane w ankiecie.

\section{Pytania pośrednie}

Poniżej zaprezentowano przykładowy zestaw pytań pośrednich do pytań głównych A i B zamieszczonych $\mathrm{w}$ ankiecie oraz odpowiedzi i punktację stosowana przy ich ocenie.

Pytanie nr 2 - Czy był(a) Pan(i) kierowany(a) na szkolenia?

a) tak,

b) nie.

Pytanie nr 4 - W związku z dobrymi osiągnięciami firmy, jak Pan(i) uważa, od jak dawna doskonali się u Państwa system jakości?

a) więcej niż 10 lat,

b) od 5-10 lat - odpowiedz poprawna dla badanego zakładu,

c) mniej niż 5 lat.
Pytanie nr 5 - Czy instrukcje posiadają procedury?

a) tak,

b) nie,

c) nie wiem.

Pytanie nr 14 - Czy przy wykonywaniu zadań potrzebna jest Panu(i) pomoc kierownictwa?

a) tak,

b) nie,

c) czasami.

W wyniku analizy ankiety stwierdzono, że badani pracownicy przeszli w 100\% wymagane szkolenia z zakresu systemów zarządzania jakością, nie posiadaja jednak nawet dostatecznej wiedzy na ten temat. Poprawne odpowiedzi na podstawowe pytania testowe 4., 5. uznawano za dostateczny poziom wiedzy. Odpowiedź na pytanie 14. oceniano jako poziom przekonania o swoich praktycznych umiejętnościach. Stwierdzono, że żadna z 12 pytanych osób nie udzieliła dwóch poprawnych odpowiedzi na podstawowe pytania testowe 4., 5. z zakresu zarządzania jakością. Szkolenia zatem były całkowicie nieefektywne. Samoocena praktycznych umiejętności wypadła w 3 przypadkach jako absolutnie wystarczająca, w 8 zadowalająca, a jedynie w 1 niezadowalająca. Łącząc obie grupy pytań można przypuszczać, że szkolenia upewniły pracowników o swojej wiedzy przy faktycznej niewiedzy. Możliwe także, że przekonanie to jest wynikiem odnoszenia swojej wiedzy do wiedzy przełożonych.

Na podstawie odpowiedzi na pytanie C, czy widoczna jest jakaś zależność pomiędzy stosunkiem pracowników do nowo wdrożonego ZSZJ a ich udziałem w procesie wdrażania, nie stwierdza się jednoznacznej zależności.

Pytania pośrednie do pytania głównego $\mathrm{C}$ oraz punktacja:

Pytanie nr 10 - Ile czasu spędzonego dziennie w pracy poświęcił Pan(i) na wdrażanie systemu jakości? 
a) większość - 3,

b) $1 / 2-2$,

c) $<1 / 2-1$,

d) $0-0$.

Pytanie nr 11 - Czy integracja obecnego systemu $\mathrm{z}$ innymi systemami powodowałaby wzrost korzyści?

a) tak - 1 ,

b) nie - 0 ,

c) nie wiem - 0 .

Pytanie nr 13 - Czy uważa Pan(i), że przy przechodzeniu $\mathrm{z}$ jednego systemu na inny należy zmienić wszystkie wchodzące w niego elementy?

a) tak -0 ,

b) nie -1 ,

c) nie wiem - 0 .

Pytanie nr 15 - Czy częste kontrole upewniaja Pana/Panią, że praca jest dobrze wykonywana?

a) tak - 1 ,

b) nie - 0 ,

c) nie wiem -0 .

Ostatnie pytanie D pozwalało na ocenę realizacji założeń stawianych przed ZSZJ oraz wprowadzonego elektronicznego systemu przesyłaniua dokumentów.

Pytania brane pod uwagę do analizy pytania głównego D oraz odpowiedzi:

Pytanie nr 8 - Czy Pana zdaniem wzrosło obciążenie pracą w ciągu ostatnich lat?

a) tak,

b) nie,

c) nie wiem.

Pytanie nr 9 - Czy w pełni ufa Pan informacji komputerowej w firmie?

a) tak,

b) nie,

c) nie wiem.

Pytanie nr 12 - Czy dalsza integracja z innymi systemami powodowałaby znaczacy wzrost biurokracji? a) tak,

b) nie,

c) nie wiem.

Z szacunku (zob. rys. 1) wynika, że scalenie systemów jakości między oddziałami oraz redukcja etatów pełnomocników (z czterech do jednego) pozwoliłyby na obniżenie jednego ze składników kosztów: dokumentacji systemowej.

Jednak zakładany spadek ilości zużycia papieru oraz spadek kosztów utrzymania dokumentacji nie został osiągnięty - stwierdzono znaczny wzrost liczby przepływających papierowych dokumentów. Przypuszcza się, że spowodowane jest to brakiem zaufania pracowników do wdrożonego systemu informatycznego.

Z wywiadów z pracownikami wynika równiez, że w dalszym ciagu są przyzwyczajeni do korzystania z drukowanej formy dokumentów. W efekcie wykonują podwójną pracę i odczuwają zarówno wzrost biurokracji, jak i zwiększenie obciążenia praca. Badania liczby przepływu dokumentów także w kilku innych działach ujawniły ich wzrost, co potwierdza występowanie znacznych błędów systemowych.
Scalenie systemów spowodowało faktycznie wzrost i tak już dużego formalizmu wprowadzonego wcześniejszymi systemami. Reorganizacja jest na tyle dobra, na ile ułatwia pracę i zwiększa zyski zakładu.

\section{Wnioski}

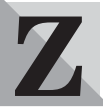

przeprowadzonych badań efektów zmian wprowadzonych w zakładzie w związku z wdrożeniem zintegrowanego systemu zarządzania jakością oraz zastosowaniem elektronicznego przesyłu dokumentów można sformułować następujące wnioski.

- Założenia stawiane przed wdrożeniem elektronicznej wersji dokumentacji systemowej nie są realizowane, a w znacznym stopniu nie mogły być zrealizowane. Powody są różne; sądzimy jednak, że w dużym stopniu nie ma zapotrzebowania na ten system. Jest mało przydatny i dlatego przez większość jest odbierany negatywnie. Oczywiście można to także tłumaczyć nieodpowiednimi kwalifikacjami kadry pracowniczej, np. brakiem przygotowania załogi do posługiwania się komputerami. Zasadniczym jednak powodem jest przyjęcie koncepcji, że najistotniejszym elementem jest wolne przesyłanie informacji, gdy faktycznie błąd znajduje się całkowicie gdzie indziej - sądzimy, że w znacznym zbiurokratyzowaniu systemu.

- Efekt wdrożenia elektronicznej wersji dokumentacji i ZSZJ jest odwrotny od zamierzonego. Pracownicy po wdrożeniu zintegrowanego systemu zarządzania jakością odczuwają wzrost obciążenia pracą oraz wzrost biurokracji.

- Z szacunków wynika, że scalenie systemów jakości między oddziałami pozwoliło na pozorne obniżenie kosztów. Nie wiadomo jednak, czy oszacowane zyski mogą zrekompensować koszty związane z wdrożeniem zintegrowanego systemu zarządzania jakością.

- Sądziliśmy, że nastawienie pracowników do ZSZJ zależne jest od zaangażowania w proces wdrażania i że pracownicy, widząc w tym swój wkład, będą mieli pozytywne nastawienie. Nie stwierdziliśmy jednak takiej zależności.

\author{
prof. dr hab. inż. Jacek Mazurkiewicz \\ Wydział Organizacji i Zarzadzania \\ Politechnika Śląska \\ mgr inz. Marzena Mendzik \\ dr inż. Janusz Kliś
}

\section{BIBLIOGRAFIA}

[1] FLEJSZMAN-MATUSZEK A., Jak skutecznie wdrożyć system zarzadzania środowiskowego wg normy ISO 14001, Polskie Zrzeszenie Inżynierów i Techników Sanitarnych, Poznań 2001.

[2] KACZMARCZYK S., Badania marketingowe, metody i techniki, PWE, Warszawa 1995.

[3] KARKOSZKA T., Systemy zintegrowanego zarzadzania a podejście procesowe.

[4] KUC B.R., Zarzadzania doskonate, Wyd. Menedżerskie PTM, Warszawa 2000.

[5] MAZUREK-ŁOPACIŃSKA K., Badania marketingowe w polskich przedsiębiorstwach, Wrocław 1996. 